\title{
Integrating MATLAB in teaching linear programming at the university level
}

\author{
Erna Puji Astutik ${ }^{1 *}$, Sri Rahmawati Fitriatien ${ }^{2}$ \\ Universitas PGRI Adi Buana Surabaya, Jl. Ngagel Dadi III No.3B/37 Surabaya, Indonesia
}

\begin{tabular}{ll}
\hline $\begin{array}{l}\text { A R T I C L E I N F O } \\
\text { Original Article }\end{array}$ & A B S T R A C T \\
doi: 10.18860/ijtlm.v1i2.5882 & Learning in higher education is inseparable from the role of \\
\hline Keywords: & lecturers in preparing learning, one of which is by preparing \\
MATLAB, & learning media that can help and guide students in understanding \\
Programming, & the material. One of the software that can be developed as a media \\
Education & in mathematics learning is MATLAB. This descriptive research \\
& used the integration of MATLAB in teaching and learning linear \\
& programming. The subject of this research were students in \\
& mathematics education class 2016B Universitas PGRI Adi Buana \\
& Surabaya. Data were collected by observation and questionnaire. \\
& From the data, can be concluded that by utilizing MATLAB on \\
& Linear Programming, students were able to use the MATLAB in \\
& understanding and solving Linear Programming problems. Students \\
also gave positive responses toward the integration of MATLAB in & linear programming teaching and learning.
\end{tabular}

(C) 2018 IJTLM. All rights reserved.

*Corresponding author.
E-mail: erna_pa@unipasby.ac.id

How to cite: Astutik, E. P., \& Fitriatien, S. R. (2018). Integrating MATLAB in teaching linear programming at the university level. International Journal on Teaching and Learning Mathematics, $1(2), 84-89$.

\section{INTRODUCTION}

Mathematics is one of the sciences that has an important role in daily life and is needed in other subjects (Acharya, 2017; Das \& Das, 2013; Furner \& Kumar, 2007; Smith \& Hausafus, 1998; Watson, 2018). By learning mathematics, students are expected to be able to understand mathematical concepts and use them in problem solving. Mathematics is one of the compulsory subjects at all school levels both in elementary and secondary schools. Therefore, professional mathematics teachers are needed in producing students who can understand, master and apply mathematics in problem solving (Jacob, Hill, \& Corey, 2017; Schoenfeld, 2010). One of the universities that concern in teaching and learning mathematics is Universitas PGRI Adi Buana Surabaya. As a result, the ability of students which are mathematics teacher candidates must be highly considered, one of which is by providing good quality of learning and being liked by students so that it will generate interest in learning which will ultimately improve learning outcomes.

Learning in higher education is inseparable from the role of lecturers in preparing learning, one of which is by preparing learning media that can help and guide students in understanding the material presented (Kristanti et al., 2018). However, current learning, especially mathematics, only presents exercises that are less interesting and easy to make students feel bored when they continue to do the exercises. Therefore, in this era of globalization, lecturers can take advantage of the technological advances that are developing today, namely by 
integrating computers and smartphones in learning, which is currently almost all students cannot be separated from the use of smartphones in their daily lives.

The use of technology in learning allows the learning process to take place individually (individual learning) which can foster individual learning where students can repeat the material that has not been understood by doing the exercises independently through software available on computers or smartphones. One software that can be integrated in mathematics learning is MATLAB software. MATLAB (Matrix Laboratory) is a software developed by Mathworks.Inc. (see http://www.mathworks.com) which is a program for numerical analysis and computation and is an advanced mathematical programming language formed with a rationale using the properties and form of a matrix. MATLAB has developed into a sophisticated programming that contains built-in functions for performing signal processing tasks, linear algebra, and other mathematical calculations. The advantages of this software compared to other software, namely MATLAB software can help graph visualization and also help train students' reasoning skills (Gil, 2017; Majid et al., 2013; Otto \& Denier, 2005; Talbert, 2013).

In the Operational Research course, especially in the Linear Programming material students are expected to understand the concept of the system of linear equations and inequalities $n$ variables and apply them in solving linear programming problems, as well as applying appropriate procedures to solve linear programming problems related to real problems and analyze the correctness of the steps (Mallet \& De Simone, 2015; Zulfikarijah, 2004). Based on observations in the Research Operational class at Universitas PGRI Adi Buana Surabaya, students have difficulty in solving the Linear Programming problems with three variables or more that have to be solved by the Simplex Method. Therefore, students should be introduced to technology or software in learning especially those that can help solve Linear Programming problems with three or more variables. One software that can be used in solving Linear Programming problems is MATLAB. The use of MATLAB software is very helpful in solving linear programming problems in which MATLAB can be used when starting to draw graphs and determine completion test points, as well as testing the optimum function at these points (UMS, 2013). There was a previous research involving technology in solving linear programming problems, it has been done by Rosiyanti (2016) using LINDO software combined with guided discovery learning methods. In that study, LINDO software was used by mathematics education students. In general, there was an increase in learning motivation for linear programming subjects with guided discovery learning methods assisted by LINDO software reaching $75.11 \%$ so that it could be said that LINDO software became an alternative software for use in learning. However, lack of research that has been conducted implementing the MATLAB software in linear programming. By integrating MATLAB software on Linear Programming, students are expected to be able to utilize the MATLAB software to understand and solve problems related to the Linear Programming.

This study focused on the application of MATLAB software on Linear Programming. The objective of this research is to describe the integration of MATLAB software in teaching and learning linear programming. It is expected that the application of MATLAB software can be used as an independent learning media as well as a learning media in the classroom to help students understand the concepts and solve Linear Program problems.

\section{METHOD}

This research used descriptive study which aimed to describe the integration of MATLAB in teaching and learning linear programming. This research was conducted in mathematics 
education study program Universitas PGRI Adi Buana Surabaya during Operational Research class in 2016 B class of 2017-2018 Academic Year. In this study, data collection was done by observation, test, and the distribution of student response questionnaires. Observation was made to find out the students' activity during the implementation of MATLAB software in linear programming class, while test was conducted to measure students' ability to solve linear programming problems. The distribution of student response questionnaires was conducted to determine student responses to the integration of MATLAB in teaching and learning linear programming. The data from the observation, test, and questionnaire were then described to explain the process and result of the integration of MATLAB software in teaching and learning linear programming

\section{RESULTS AND DISCUSSION}

The implementation was conducted three times during Operational Research Class. First, students were explained about linear programming and solve it by graphical and simplex method. However, students still have many difficulties in solving simplex problems. After that, students were introduced the MATLAB software including the function and how to use the software. Students were then given the task related to linear programming and solve it using MATLAB software. From the task, can be obtained the average value of students' ability to solve linear programming problems by using MATLAB is 83.10 where the average value is classified as high.

The students' activity during implementation were also measured by observation. The result of the observation is described in Figure 1.

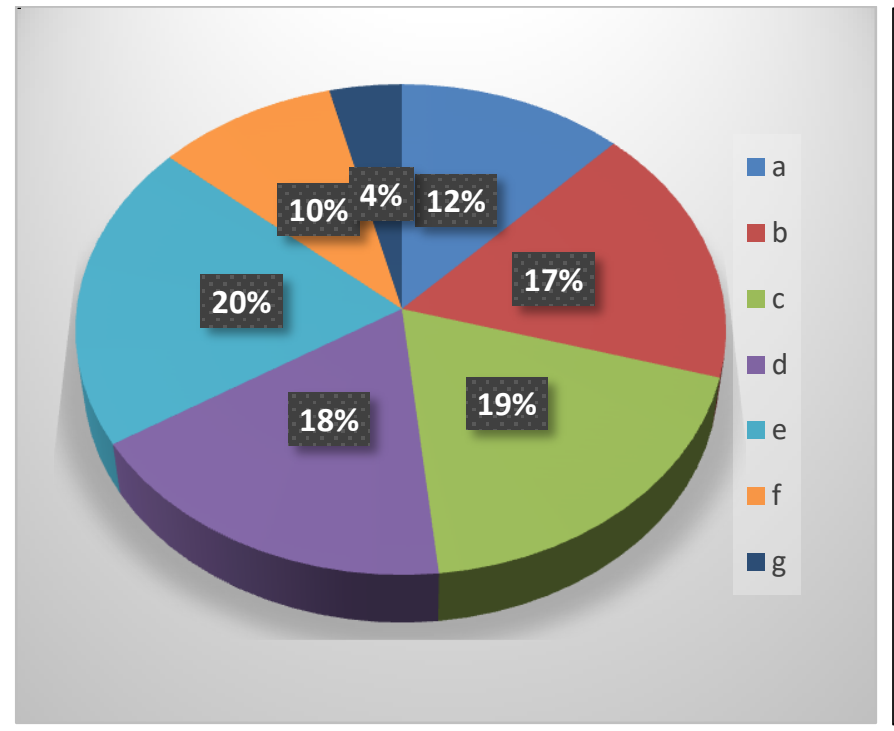

Description of Figure 1:

a. Pay attention to, record the explanation of the lecturer/friend

b. Work on the problem

c. Discussion/question and answer between students and lecturer

d. Discussion/question and answer between students and students

e. Present the results of the discussion/enhance responses or ask friends/lecturers

f. Draw conclusions/summarize the subject matter

g. Behavior that is not relevant to teaching and learning (for example: conversations outside of learning, walking outside the group, doing something outside the topic of learning, etc.)

Figure 1. Students' activity during the integration of MATLAB in linear programming

From the Figure 1 can be described that students were active in classroom with the total percentage of $96 \%$ students' activity related to the teaching and learning in which $12 \%$ students paid attention to, recorded the explanation of the lecturer / friend; $17 \%$ students worked on the problem; 19\% students discussed or asked question to lecturer; $18 \%$ students discussed or asked question to other students; $20 \%$ students presented the results of the discussion/enhanced responses or ask friends / lecturers; $10 \%$ drew conclusions/summarized the subject matter. 
While, $4 \%$ students did the activity that is not relevant to teaching and learning (for example: conversations outside of learning, walking outside the group, doing something outside the topic of learning, etc.)

During the implementation, students were also given questionnaire to gather students' responses toward the teaching and learning by integrating MATLAB. The data from the questionnaire are described in Table 1.

Table 1. Students' responses toward the integration of MATLAB in linear programming

\begin{tabular}{llcc}
\hline \multirow{2}{*}{ No } & \multicolumn{1}{c}{ Question } & \multicolumn{2}{c}{ Percentage (\%) } \\
\cline { 3 - 4 } & & Yes & No \\
\hline 1. & Is the implementation of MATLAB software in linear programming fun? & 84.21 & 15.79 \\
2. & Do you understand linear programming material with the implementation of & 68.42 & 31.58 \\
3. & Can you use MATLAB software to solve linear programming problems? & 68.42 & 31.58 \\
4. & $\begin{array}{l}\text { Do you have difficulties in solving linear programming problems using } \\
\text { MATLAB software? }\end{array}$ & 26.32 & 73.68 \\
\hline
\end{tabular}

From the Table 1 can be described that from the first question (Is the implementation of MATLAB software in linear programming fun?) 84.21\% students answered "Yes" and $15.79 \%$ students answered "No". For the second question (Do you understand linear programming material with the implementation of MATLAB software?) $68.42 \%$ students answered "Yes" and $31.58 \%$ students answered "No". For the third question (Can you use MATLAB software to solve linear programming problems?) also got the same answer which were $68.42 \%$ students answered "Yes" and 31.58\% students answered "No". For the last question (Do you have difficulties in solving linear programming problems using MATLAB software?) $26.32 \%$ students answered "Yes" and 73.68\% students answered "No".

In addition, from the questionnaire also obtained the reasons for student answers as follows.

1. The implementation of MATLAB software in linear programming is fun, because:

a. Making linear programming work easier

b. Faster in determining the results

c. Minimizing the time to answer the questions

d. No need to manually count

e. The MATLAB software is easy to implement in finding the maximization and minimization problems

f. Learning is more interesting

2. Students understand linear programming material with the implementation of MATLAB software, because:

a. More interesting, easier and faster in calculating and understanding the learning material

b. Problems that cannot be solved manually, but can be completed with the program

3. Students can use MATLAB software to solve linear programming problems, because:

a. Guided by the lecturer

b. Understand the key format in using MATLAB

c. The process steps are easy to understand

d. We only enter numbers in MATLAB without doing complicated calculation 
From the result of the research can be analyzed that during the integration of MATLAB in Linear Programming, students actively work in classroom by utilizing MATLAB in which the total percentage of students' activity related to learning is $96 \%$. Students were also able to use MATLAB to understand and solve problems related to Linear Programming. It can be seen from students' ability to solve linear programming problems by using MATLAB is 83.10 where the average value is classified as high. Students also gave positive responses that $84.21 \%$ students enjoying the learning by using MATLAB. This result in line with Han (2009) which the students responded positively about using MATLAB in Linear Algebra class.

MATLAB also helped the students in finding the optimum solution of the linear programming problems without doing more calculation. In solving linear programming, students usually used graphical and simplex method. However, many of them got difficulties in solving linear programming problems by using simplex method. This also mentioned by some authors in which students still have many difficulties in solving simplex problems which include: data errors, sign errors, errors in making mathematical modeling, errors in using definitions or theorems, calculation errors, and solutions that are not re-examined (Arsham et al., 2005; Bixby et al., 1992; Gass, 2003; Moyer, 2017). By using MATLAB, students are able to minimize the errors in calculation as long as they understand the formula and function in MATLAB.

However, there were $15.79 \%$ students did not enjoy the learning by using MATLAB and $31.58 \%$ students did not think that MATLAB would help them in solving the Linear Programming. This result also in line with Han (2009) in which $43 \%$ of students responded that MATLAB would not help the in solving in Linear Algebra problem. In addition, 26.32\% students got difficulties in solving Linear Programming problems by using MATLAB because MATLAB can only solve Linear Programming problems in standard form. Therefore, students have to convert the problems to standard form before solving using MATLAB.

\section{CONCLUSION}

This study reported that MATLAB is suitable to be applied in linear programming teaching and learning. Students were able to use MATLAB to understand and solve problems related to the Linear Programming. Students also responded positively toward the implementation of MATLAB in linear programming teaching and learning. However, MATLAB can only solve Linear Programming problems in standard form. Therefore, students have to convert the problems to standard form before solving using MATLAB.

\section{REFERENCES}

Acharya, B. R. (2017). Factors affecting difficulties in learning mathematics by mathematics learners. International Journal of Elementary Education, 6(2), 8-15.

Arsham, H., Cimperman, G., Damij, N., Damij, T., \& Grad, J. (2005). A computer implementation of the Push-and-Pull algorithm and its computational comparison with LP simplex method. Applied mathematics and computation, 170(1), 36-63.

Bixby, R. E., Gregory, J. W., Lustig, I. J., Marsten, R. E., \& Shanno, D. F. (1992). Very largescale linear programming: A case study in combining interior point and simplex methods. Operations Research, 40(5), 885-897.

Das, R., \& Das, G. C. (2013). Math anxiety: The poor problem solving factor in school mathematics. International Journal of Scientific and Research Publications, 3(4), 1-5. 
Furner, J. M., \& Kumar, D. D. (2007). The mathematics and science integration argument: A stand for teacher education. Eurasia Journal of Mathematics, Science and Technology Education, 3(3), 185-189.

Gass, S. I. (2003). Linear programming: Methods and applications. Courier Corporation.

Moyer, T. O. (2017). The simplex method for systems of linear inequalities. Ohio Journal of School Mathematics, 74(2), 15-21.

Gil, P. (2017). Short project-based learning with MATLAB applications to support the learning of video-image processing. Journal of Science Education and Technology, 26(5), 508-518.

Han, X. (2009). Teaching elementary linear algebra using MATLAB: An initial investigation. The Scholarship of Teaching and Learning at EMU, 2(1), 171-182.

Jacob, R., Hill, H., \& Corey, D. (2017). The impact of a professional development program on teachers' mathematical knowledge for teaching, instruction, and student achievement. Journal of Research on Educational Effectiveness, 10(2), 379-407.

Kristanti, F., Ainy, C., Shoffa, S., Khabibah, S., \& Amin, S. M. (2018). Developing creativeproblem-solving-based student worksheets for transformation geometry course. International Journal on Teaching and Learning Mathematics, 1(1), 13-23.

Majid, M. A., Huneiti, Z. A., Balachandran, W., \& Balarabe, Y. (2013). MATLAB as a teaching and learning tool for mathematics: a literature review. International Journal of Arts \& Sciences, 6(3), 23-44.

Mallet, F., \& De Simone, R. (2015). Correctness issues on MARTE/CCSL constraints. Science of Computer Programming, 106, 78-92.

Otto, S., \& Denier, J. P. (2005). An introduction to programming and numerical methods in $M A T L A B$. USA: Springer Science \& Business Media.

Rosiyanti, H. (2016). Penggunaan software lindo dengan metode pembelajaran penemuan terbimbing untuk meningkatkan motivasi belajar mahasiswa matematika angkatan 2013 pada matakuliah program linier. FIBONACCI: Jurnal Pendidikan Matematika dan Matematika, 2(2), 19-27.

Schoenfeld, A. H. (2010). How we think: A theory of goal-oriented decision making and its educational applications. New York: Routledge.

Smith, F. M., \& Hausafus, C. O. (1998). Relationship of family support and ethnic minority students' achievement in science and mathematics. Science Education, 82(1), 111-125.

Steen, L. A. (2001). Mathematics and numeracy: Two literacies, one language. The mathematics educator, 6(1), 10-16.

Talbert, R. (2013). Learning MATLAB in the inverted classroom. The ASEE Computers in Education (CoED) Journal, 4(2), 89-100.

UMS, T. F. (2013). Modul III linear programming dan visualisasi. Surakarta: Fakultas Teknik Universitas Muhammadiyah Surakarta.

Watson, E. (2018). Why Teach High School Mathematics? Integrating Mathematics with Other School Subjects. Alberta Science Education Journal, 45(3), 5-13.

Zulfikarijah, F. (2004). Operation research. Malang: Bayumedia Publishing. 